\title{
Reduction of Garbage in the Diet of Nonbreeding Glaucous Gulls Corresponding to a Change in Waste Management
}

\author{
EMILY L. WEISER ${ }^{1}$ and ABBY N. POWELL ${ }^{2}$
}

\author{
(Received 16 April 2010; accepted in revised form 28 September 2010)
}

\begin{abstract}
Glaucous gulls (Larus hyperboreus) are major predators in the Arctic and may benefit from human development. We studied use of garbage by glaucous gulls in Barrow, Alaska, in 2007, when municipal waste was disposed of in a landfill, and in 2008, when it was incinerated. In both years, diet samples from breeding adult gulls contained less garbage than those from loafing nonbreeding gulls (mostly subadults of less than four years), possibly because the breeding colony was more distant than many loafing sites from the landfills. Although breeding gull samples showed no change, garbage in regurgitated pellets and food remains of nonbreeding gulls was significantly less prevalent in 2008 than in 2007 (28\% vs. 43\% occurrence in diet samples), and this reduction could be explained by the switch from landfill to waste incineration. Yet garbage remained a substantial part of nonbreeding gull diet after the management change. Other aspects of waste management, such as storage prior to disposal, may also be important in limiting scavengers' access to garbage and thus reducing the indirect impact of human development on prey species of conservation concern.
\end{abstract}

Key words: development, diet, glaucous gull, human refuse, human-subsidized predators, Larus hyperboreus, management

RÉSUMÉ. Dans l'Arctique, le goéland bourgmestre (Larus hyperboreus) est un important prédateur, et celui-ci pourrait bénéficier du développement humain. Nous nous sommes penchés sur l'utilisation qu'a fait le goéland bourgmestre des déchets à Barrow, en Alaska, en 2007 lorsque les déchets municipaux aboutissaient dans un site d'enfouissement puis en 2008, lorsque les déchets municipaux étaient incinérés. Au cours de ces deux années, les échantillons alimentaires prélevés chez les goélands adultes reproducteurs renfermaient moins de déchets que les échantillons prélevés auprès des goélands non-reproducteurs qui flânaient (des goélands immatures de moins de quatre ans dans la plupart des cas), probablement parce que la colonie de reproduction était plus loin des sites d'enfouissement que des nombreux lieux de flânerie. Bien que les échantillons prélevés chez les goélands reproducteurs ne laissent entrevoir aucun changement, les déchets se trouvant dans les pelotes de régurgitation et les restes d'aliments des goélands non-reproducteurs étaient beaucoup moins considérables en 2008 qu'en 2007 (soit une occurrence de $28 \%$ par rapport à $43 \%$ dans les échantillons alimentaires), réduction qui pourrait être attribuable au fait que les déchets étaient incinérés et non plus enfouis. Pourtant, les déchets constituaient toujours une partie importante du régime alimentaire des goélands non-reproducteurs après que la méthode d'élimination des déchets a subi des changements. D'autres aspects de la gestion des déchets, tels que le stockage des déchets avant leur élimination, pourraient également jouer un rôle important quand vient le temps de restreindre l'accès de ces charognards aux déchets, ce qui aurait pour effet de réduire les incidences indirectes du développement humain sur les espèces de proies suscitant des inquiétudes en matière de conservation.

Mots clés : développement, régime, goéland bourgmestre, déchets humains, prédateurs assistés par les humains, Larus hyperboreus, gestion

Traduit pour la revue Arctic par Nicole Giguère.

\section{INTRODUCTION}

Human-subsidized predators benefit from associating with development, often through use of food waste or artificial breeding sites (Gompper and Vanak, 2008). In some cases, this benefit can allow predator population numbers or densities to increase (Steenhof et al., 1993; National Research Council, 2003; Contesse et al., 2004). If these predators also feed on natural prey, their anthropogenically enhanced populations could have negative consequences for prey species, including reduced reproductive output, diminished populations, or even extinction (Holt, 1984; Garrott et al., 1993). Effects of human activity on predators are therefore of great interest to conservation efforts in developed or developing areas.

One group of human-subsidized predators is Larus gulls, which experienced worldwide population growth during the 20th century (Kadlec and Drury, 1968; Fordham and

\footnotetext{
${ }^{1}$ Department of Biology and Wildlife, University of Alaska Fairbanks, PO Box 756100, Fairbanks, Alaska 99775, USA; Corresponding author: emily.1.weiser@gmail.com

${ }^{2}$ U.S. Geological Survey, Alaska Cooperative Fish and Wildlife Research Unit and Institute of Arctic Biology, University of Alaska Fairbanks, PO Box 757020, Fairbanks, Alaska 99775, USA
} 
Cormack, 1970; Harris, 1970; Conover, 1983; Yorio et al., 1998). A likely cause of this trend was a general increase in the availability of anthropogenic foods, including household garbage and discards from fisheries, which may have improved gull survival or reproductive success, or both (Fordham and Cormack, 1970; Conover, 1983; Chapdelaine and Rail, 1997; Duhem et al., 2008). Future development may similarly cause gull population growth unless gull access to anthropogenic subsidies is limited.

The Arctic Coastal Plain (ACP) of Alaska, USA, is particularly susceptible to the impacts of future development. Widespread oil exploration began on the ACP in the 1950s; development for production began in the 1970s and continues today (National Research Council, 2003). Further development is expected as additional areas of the National Petroleum Reserve-Alaska are leased and explored for production. The potential effects of development on ACP wildlife are of great concern because this region supports many tundra-nesting birds. Of the 40 species of waterfowl and shorebirds that breed in the area (Poole, 2007), 28 have declined or are listed as species of moderate to high conservation concern, and two are listed as threatened under the U.S. Endangered Species Act (Table 1). Alaska Natives in the region hunt some of these birds for subsistence, so factors influencing population trends in these species could have implications for human residents as well as for conservation efforts.

The most abundant predator that may benefit from municipal waste on the ACP is the glaucous gull (Larus hyperboreus; Liebezeit et al., 2009), with a local population of about 11000-14000 individuals (Larned et al., 2010). Among other prey, these gulls feed on eggs, young, or adults of at least 19 species of waterfowl and shorebirds (Weiser, 2010). Reproductive success of glaucous gulls in this area is positively associated with the amount of garbage in the gulls' diets (Weiser and Powell, 2010), so development with an associated increase in garbage availability may cause gull population growth. Unfortunately, historical data on glaucous gull numbers on the ACP are scarce, so it is not clear whether populations have increased in response to past development (Noel et al., 2006). However, there is anecdotal evidence that glaucous gull densities may have increased in developed areas of western and northern Alaska in recent decades (Springer, 1987; USFWS, 2003). Moreover, recent aerial surveys have revealed higher concentrations of glaucous gulls near villages and oilfields than in surrounding undeveloped areas (Noel et al., 2006). The cause of this pattern is not clear, but one possibility is that anthropogenic foods support or attract higher densities of gulls than undeveloped areas.

If anthropogenically enhanced numbers of glaucous gulls could be detrimental to populations of prey species, it will be important to prevent this effect from becoming more widespread with future development. Waste management strategies can limit the benefit predators and scavengers receive from human subsidies (Curtis et al., 1995; Kurosawa et al., 2003), but their effects are not often quantified. If effective, such strategies may be of interest to future developers on the ACP.

We used regurgitated pellets and food remains to quantify the use of human food waste and natural food items by glaucous gulls in one region of the ACP. During our study, waste management in the area switched from dumping putrescible waste in a traditional landfill to incinerating it. We tested for a reduction of garbage in gull diet corresponding to the change in waste management. We also compared the diets of loafing (nonbreeding; Spear, 1988) and breeding adult gulls to determine whether the benefit derived from garbage changed with age or breeding status or both, and we tested for a potential effect of distance to landfill on the amount of garbage in gull diet at each site. The effect of waste incineration on gull diet will be relevant to developers and managers in areas where current or future gull population growth would be detrimental to local wildlife or human residents.

\section{METHODS}

\section{Study Area}

This study was conducted in Barrow, Alaska, USA $\left(71^{\circ} 18^{\prime} \mathrm{N}, 156^{\circ} 45^{\prime} \mathrm{W}\right)$, a city with about 4000 residents located on the ACP (Fig. 1). A variety of shorebirds and waterfowl, loons, ptarmigan, and sparrows nest on the ACP; lemmings, voles, and freshwater and marine fish are also available as potential prey. Subsistence-hunted whale, seal, caribou, and waterfowl carcasses are often available to be scavenged near residential areas.

Barrow is not accessible by road, and the nearest major city (Fairbanks, Alaska) is 500 miles (ca. $800 \mathrm{~km}$ ) to the south. Barrow's remote nature makes it highly impractical to ship waste to major processing or recycling facilities, so garbage and other waste are dealt with locally. Until mid July 2007, a landfill northeast of town was used for disposal of household waste; since then, waste has been incinerated and the ashes deposited in a new landfill southeast of town (Fig. 1). Fresh waste continued to be available in open dumpsters at the old landfill throughout the summer of 2007 as the city switched over to the new system. When describing gull diet under different management regimes, we therefore considered 2007 to represent the traditional landfill, and 2008 to represent the new waste incineration strategy. In both years, household waste was available in open dumpsters around the city before being deposited in the landfill or incinerated.

\section{Diet Analysis}

We characterized glaucous gull diet at eight to nine loafing sites around Barrow, Alaska in each year (Fig. 1). Since most gulls that use loafing sites are subadults (which do not breed) or nonbreeding adults (Spear, 1988), we used these sites to characterize nonbreeding gull diet. In an effort to 
TABLE 1. Waterfowl and shorebird species of conservation concern that breed on the Arctic Coastal Plain of Alaska (Poole, 2007) and the conservation status of each.

\begin{tabular}{|c|c|c|}
\hline Common name & Latin name & Status \\
\hline Black-bellied plover & Pluvialis squatarola & Moderate concern ${ }^{1}$ \\
\hline American golden-plover & Pluvialis dominica & High concern; declining ${ }^{1}$ \\
\hline Whimbrel & Numenius phaeopus & High concern ${ }^{1}$ \\
\hline Bar-tailed godwit & Limosa lapponica baueri & High concern; declining ${ }^{1}$ \\
\hline Ruddy turnstone & Arenaria interpres interpres & Moderate concern ${ }^{1}$ \\
\hline Red knot & Calidris canutus roselaari & High concern; declining ${ }^{1}$ \\
\hline Sanderling & Calidris alba & High concern; declining ${ }^{1}$ \\
\hline Semipalmated sandpiper & Calidris pusilla & Moderate concern; declining ${ }^{1}$ \\
\hline Western sandpiper & Calidris mauri & High concern; declining ${ }^{1}$ \\
\hline Least sandpiper & Calidris minutilla & Moderate concern; declining 1 \\
\hline White-rumped sandpiper & Calidris fuscicollis & Moderate concern; declining ${ }^{1}$ \\
\hline Dunlin & Calidris alpina arcticola & High concern; declining ${ }^{1}$ \\
\hline Stilt sandpiper & Calidris himantopus & Moderate concern ${ }^{1}$ \\
\hline Buff-breasted sandpiper & Tryngites subruficollis & High concern; declining ${ }^{1}$ \\
\hline Long-billed dowitcher & Limnodromus scolopaceus & Moderate concern ${ }^{1}$ \\
\hline Wilson's snipe & Gallinago delicata & Moderate concern; declining ${ }^{1}$ \\
\hline Red-necked phalarope & Phalaropus lobatus & Moderate concern; declining ${ }^{1}$ \\
\hline Red phalarope & Phalaropus fulicarius & Moderate concern; declining ${ }^{1}$ \\
\hline Black brant & Branta bernicla nigricans & Declining $^{2}$ \\
\hline Cackling goose & Branta hutchinsii & Declining $^{2}$ \\
\hline Mallard & Anas platyrhynchos & Declining $^{2}$ \\
\hline Northern pintail & Anas acuta & Declining $^{2}$ \\
\hline Greater scaup & Avthya marila & Declining $^{2}$ \\
\hline Steller's eider & Polysticta stelleri & Threatened $^{3}$ \\
\hline Spectacled eider & Somateria fischeri & Threatened $^{3}$ \\
\hline King eider & Somateria spectabilis & Past declines ${ }^{4}$ \\
\hline Common eider & Somateria mollissima & Declining $^{5}$ \\
\hline Surf scoter & Melanitta perspicillata & Declining ${ }^{6}$ \\
\hline Long-tailed duck & Clangula hyemalis & Declining $^{5}$ \\
\hline Red-breasted merganser & Mergus serrator & Declining $^{5}$ \\
\hline
\end{tabular}

${ }^{1}$ Alaska Shorebird Group, 2008.

${ }^{2}$ USFWS, 2005.

${ }^{3}$ Listed under the U.S. Endangered Species Act of 1973.

${ }^{4}$ Suydam et al., 2000.

${ }^{5}$ Dickson and Gilchrist, 2001.

${ }^{6}$ Goudie et al., 1994.

sample the entire population of nonbreeding gulls around Barrow, we collected samples at all sites where gulls were observed loafing in each year, even when sites differed between years. All sites were within $20 \mathrm{~km}$ of both landfills and the city, well within the typical daily foraging range (up to $70 \mathrm{~km}$ ) of glaucous gulls in northern Alaska (Declan Troy, Troy Ecological Research Associates, unpubl. data).

Once a week in summer (June-August) 2007 and 2008, we counted the gulls present at each loafing site. On the basis of plumage, we assigned each gull to one of two age classes that were easily discernable in the field (Gilchrist, 2001): subadult (less than four years old) and adult (at least four years old). We also collected regurgitated pellets and food remains during each site visit. These diet samples consist of indigestible parts of prey and are abundant in gull loafing and breeding areas (Gonzáles-Solís et al., 1997). To ensure the samples were produced in the current year, we did not collect items that showed evidence of weathering, such as sun-bleaching, epiphyte growth, or tannin stains. Diet data from these samples are biased against highly digestible prey (Duffy and Jackson, 1986), but the samples are appropriate for monitoring variation in consumption

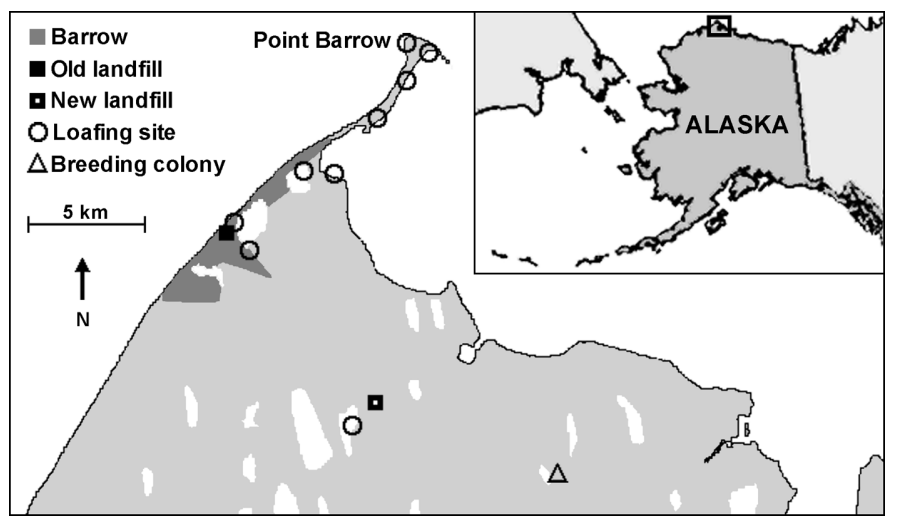

FIG. 1. Collection sites for glaucous gull diet samples in 2007 and 2008. Inset shows location of enlarged map in Alaska.

of food items with indigestible parts, including garbage (Gonzáles-Solís et al., 1997; Weiser, 2010).

In each year, we also collected diet samples from the breeding colony closest to Barrow, once in late June and once in early August (Fig. 1). Again, we did not collect weathered items to ensure samples were produced during the year of 
collection. Adult glaucous gulls regurgitate prey to feed their chicks and exclude foreign adults and subadults from the colony (Gilchrist, 2001), so all of our diet samples collected at colonies represented prey captured by breeding adults. In each year, we recorded the number of breeding pairs (based on the number of current-year nests) and counted the chicks present at the colony just prior to fledging.

\section{Data Analysis}

We calculated the percent of gulls at each loafing site that were subadults, and calculated the mean and standard deviation of percent subadults across sites within each year. We also calculated the mean and standard deviation for group size within each year. We used linear regression to test for a temporal trend in loafing group size or age composition over the course of the summer in each year and Mann-Whitney $\mathrm{U}$ tests to test for differences between years in loafing group size or percentage of subadults. A critical significance level of 0.05 was used for these tests.

We dissected the pellets and visually examined food remains to identify the foods present in each sample. We identified prey to the lowest possible taxonomic level, but since many prey items could not be consistently identified below class, we grouped prey at class level for diet analysis and considered garbage an additional food class. For each group of gulls (breeding or nonbreeding) in each year, we recorded the number of diet samples (pellets and food remains) in which each food class occurred. We used pairwise chi-square independence tests to test for interannual differences in frequency of occurrence of each prey class in diet samples for each group of gulls, as well as for differences between nonbreeding and breeding gulls within each year. We did not conduct these tests where expected values were less than five for at least one cell. We used a significance level of 0.01 because we were making multiple comparisons (i.e., for several food types) between groups.

Finally, we used linear regression to test for a relationship between distance to active landfill (old landfill in 2007, new landfill in 2008) and percent occurrence of garbage in diet samples from each loafing site, assuming that sites were independent between years. We included only sites with five or more diet samples for each year and tested this relationship at the 0.05 significance level. We then visually assessed the breeding site data in relation to this regression to evaluate whether breeding adults may have shown a different relationship between distance to landfill and diet than nonbreeding gulls. We could not perform a regression on breeding sites because we had only two samples from the same colony, and these were likely not independent between years because individual glaucous gulls tend to return to the same breeding colony year after year (Gaston et al., 2009). To determine whether a relationship between distance to landfill and garbage in diet could explain any apparent diet differences between years, we used a Mann-Whitney U test to detect any differences between years in average distance from loafing sites to active landfill.
All analyses were conducted in program $\mathrm{R}$, version 2.9.2 (R Development Core Team, 2009).

\section{RESULTS}

Average loafing group size was $25( \pm 29)$ in 2007 and 23 $( \pm 24)$ in 2008 , and most of the gulls at each loafing site were subadults $(87 \% \pm 16 \%$ in $2007,72 \% \pm 35 \%$ in 2008$)$. Neither loafing group size nor age composition differed significantly between years $(\mathrm{U}<192, p>0.1)$, and neither was linearly related to date of observation in either year $(p>0.15)$.

We collected 193 diet samples from nonbreeding gulls at the loafing sites in 2007 and 248 samples in 2008 (Table 2). In nonbreeding gull diet samples from 2007, the most prevalent food detected was garbage, followed by birds (mostly waterfowl and shorebirds), crustaceans (unidentified crab species, the marine isopod Saduria entomon, and euphausiids), and mammals (mostly brown lemmings, Lemmиs trimucronatus). In the 2008 samples, crustaceans were most prevalent, followed by garbage, birds, and mammals (Table 2). Fish, bivalves, gastropods, insects, and unidentified prey were present in a small proportion of nonbreeding diet samples. Garbage was significantly less prevalent when the city incinerated its waste ( $28 \%$ occurrence) than when the traditional landfill was used $\left(43 \% ; \chi^{2}{ }_{1}=10.5, p=0.001\right)$. Occurrence of other prey classes did not differ significantly between years $(p>0.01)$.

The breeding colony contained 10 breeding pairs of gulls that fledged 11 chicks in 2007 and 13 pairs with 18 chicks in 2008. We collected 46 diet samples at the breeding colony in 2007 and 403 samples in 2008 (Table 2). We did not collect all samples available in 2007 because we initially planned that year to be a pilot season for a study of breeding gull diet. However, although the 2007 diet samples represented a smaller portion of the colony than the 2008 samples, the collection was not biased by diet sample type or content.

In 2007, the most common food in breeding gull diet samples was birds (mostly shorebirds with some waterfowl), followed by mammals (mostly brown lemmings with a few scavenged caribou and arctic fox), and garbage. In 2008, mammals were most common, followed by birds and garbage. Fish, crustaceans, bivalves, and unidentified prey were minor components of breeding gull diet in both years (Table 2). Garbage was present in only $7 \%$ of the diet samples from the breeding colony in 2007 and $13 \%$ in 2008, with no significant difference between years $(p>0.1)$. Mammals occurred more frequently in breeding diet samples in 2008 than in $2007\left(\chi_{1}^{2}=14.7, p<0.001\right)$. There were no other significant differences between years in occurrence of food types $(p>0.01)$.

In both years, garbage was more prevalent in diet samples from nonbreeding gulls than in those from breeding gulls (Table 2). Breeding gull diet samples contained proportionally more birds, more mammals, and fewer crustaceans than those from nonbreeding gulls in both years. We identified seven shorebird species in gull diet (Table 3), 
TABLE 2. Percent occurrence of each food class in diet samples (pellets and food remains) from nonbreeding and breeding glaucous gulls around Barrow, Alaska, when garbage was disposed of in a landfill (2007) and incinerated (2008). Occurrences do not sum to 100\% because each diet sample can contain more than one food type.

\begin{tabular}{|c|c|c|c|c|c|c|}
\hline & \multicolumn{3}{|c|}{2007 (Landfill) } & \multicolumn{3}{|c|}{2008 (Incineration) } \\
\hline & Nonbreeding & Breeding & Chi-square $^{1}$ & Nonbreeding & Breeding & Chi-square \\
\hline Garbage & 43 & 13 & $14.3^{*}$ & 28 & 7 & $54.4^{*}$ \\
\hline Mammals & 16 & 43 & $16.6^{*}$ & 22 & 71 & $150.5^{*}$ \\
\hline Birds & 33 & 59 & $10.3^{*}$ & 27 & 48 & $29.0 *$ \\
\hline Fish & 3 & 4 & - & 5 & 6 & 0.7 \\
\hline Crustaceans & 29 & 0 & $17.0 *$ & 38 & 1 & $156.6^{*}$ \\
\hline$n^{2}$ & 193 & 46 & & 248 & 403 & \\
\hline
\end{tabular}

${ }^{1}$ Chi-square tests were used to detect differences between nonbreeding and breeding gulls in frequency of occurrence of each prey class ( $\mathrm{df}=1$ and $\alpha=0.01$ for each test). Asterisks $(*)$ indicate significant differences. Bivalves, gastropods, insects (Pterygota), and unidentified items, which were present in 5\% or less of samples from each group in each year, were not tested for differences between groups.

${ }^{2}$ Number of pellets and food remains analyzed for each gull group in each year.

six of which are experiencing population declines (Alaska Shorebird Group, 2008).

For nonbreeding gulls, we found a significant relationship between distance to active landfill and percent occurrence of garbage in diet samples for loafing sites with at least five diet samples (seven sites in each year; Fig. 2). Data from breeding adults qualitatively matched this pattern. Average distance from loafing sites to active landfill (5.3 \pm $3.9 \mathrm{~km}$ in $2007,9.7 \pm 4.4 \mathrm{~km}$ in 2008 ) did not vary significantly between years $(\mathrm{U}=16.5, p>0.067)$.

\section{DISCUSSION}

The change in waste management apparently did not affect the group size or age composition of nonbreeding glaucous gulls using loafing areas around Barrow. For nonbreeding gulls, garbage was a common diet component in both years, but was significantly less prevalent after waste incineration was implemented. For breeding adults, garbage was less prevalent in the diet than for nonbreeding gulls, and its occurrence in breeding diet samples did not change with the shift in waste management.

The reduced amount of garbage in nonbreeding gull diet in 2008 compared to 2007 corresponded with a slight increase in the average distance of loafing areas from landfills. This increase in distance was not significant, but with only eight to nine sites in each year, we may not have had sufficient power to detect such a trend. However, because we sampled all areas used by gulls in each year, the differences in sites sampled reflected changes in gull use of loafing sites between years. It may be that nonbreeding gulls changed their patterns of loafing site use when less waste was available, shifting to sites that were farther from the landfills.

The relationship between distance to landfill and percent occurrence of garbage in diet samples could be explained in two ways. Gulls that spend time closer to landfills may use more waste, or gulls may choose loafing areas near the site of their last meal to digest and produce pellets. One study
TABLE 3. Percent occurrence of each shorebird species or bird taxon in diet samples (pellets and food remains) from nonbreeding and breeding glaucous gulls around Barrow, Alaska, when garbage was disposed in a landfill (2007) and incinerated (2008). Some species are easier to identify than others (e.g., phalaropes have distinctive lobed feet), so the number of occurrences identified may not be proportionally representative of the number of times the species was eaten by gulls. All species listed are declining except pectoral sandpiper, Calidris melanotos (Alaska Shorebird Group, 2008).

\begin{tabular}{lrrrrr}
\hline \hline & \multicolumn{2}{c}{ Nonbreeding } & & \multicolumn{2}{c}{ Breeding } \\
\cline { 2 - 3 } \cline { 5 - 6 } Species & 2007 & 2008 & & 2007 & 2008 \\
\hline American golden-plover & 0 & $<1$ & & 0 & 0 \\
Long-billed dowitcher & 0 & 0 & & 2 & 1 \\
Dunlin & 1 & 0 & & 4 & $<1$ \\
Pectoral sandpiper & 0 & 0 & & 2 & 1 \\
Semipalmated sandpiper & 0 & 0 & & 0 & $<1$ \\
Red phalarope & 1 & $<1$ & & 17 & 11 \\
Red-necked phalarope & 0 & $<1$ & & 0 & $<1$ \\
Total identified shorebirds & 2 & 1 & & 26 & 13 \\
Unidentified shorebird & 3 & 1 & & 13 & 8 \\
Other bird & 23 & 15 & & 11 & 9 \\
Unidentified bird & 6 & 10 & & 9 & 19 \\
\hline \hline
\end{tabular}

found that about $38 \%$ of great skua (Catharacta skua) pellets were produced within six hours of a meal (Votier et al., 2001), suggesting that gulls could produce pellets or food remains at the first loafing site used after feeding. Nonbreeding gulls may show fidelity to both foraging and loafing sites (Spear, 1988), which could explain the observed differences in diet among loafing sites.

The apparent dietary differences between breeding and nonbreeding gulls could be due to differences in gulls' access to waste. The breeding colony we studied was more distant than some loafing sites from the landfills. If breeding sites have a relationship between garbage in diet and distance to active landfill similar to the one we found for loafing sites, this factor could explain why garbage is less prevalent in breeding gull diet than in nonbreeding gull diet. 


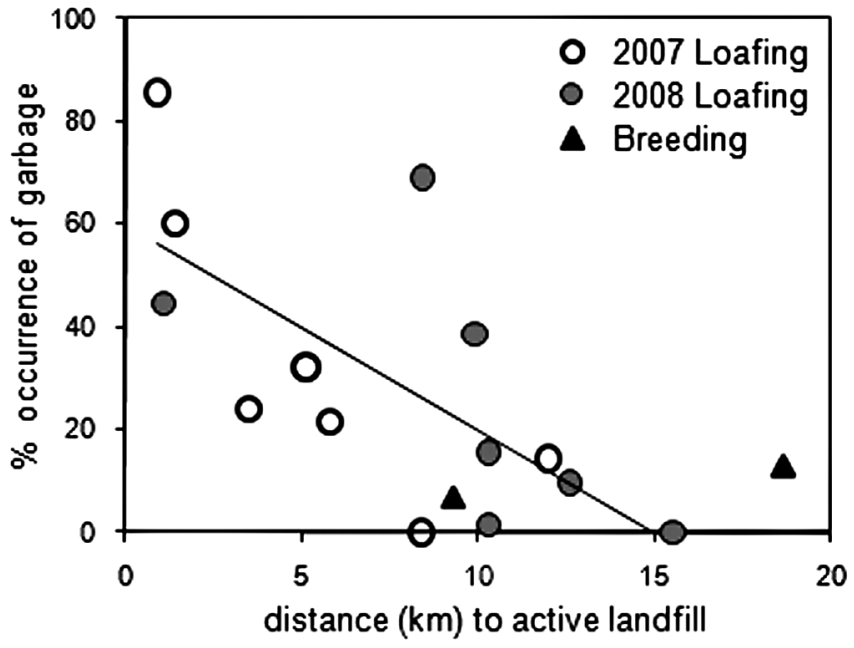

FIG. 2. Relationship between distance to landfill and percent occurrence of garbage in diet samples for glaucous gull loafing sites near Barrow, Alaska $\left(\mathrm{r}^{2}=0.47, p=0.007\right)$. The two points that represent breeding sites, though not included in the regression, fall roughly within the same space occupied by points from loafing gulls. Although two data points do not suffice to draw a conclusion, they show that the breeding data could potentially follow the pattern of the loafing data.

Glaucous gulls and other birds that experience deferred sexual maturity use their time as nonbreeding subadults to develop foraging skills (Ashmole, 1963). Subadult gulls forage less efficiently than adults on both natural foods and municipal waste (Searcy, 1978; Skórka and Wójcik, 2008), improving progressively with age (MacLean, 1986). Subadult glaucous gulls may therefore benefit from waste as a food source because it is predictably available at certain times and places and easier to obtain than natural prey, such as lemmings and shorebirds. Unlike breeding adult gulls, subadults and nonbreeding adults around Barrow did not increase their consumption of mammals (mostly brown lemmings) in 2008 despite the very high local lemming abundance in that year (Rick Lanctot, USFWS, unpubl. data). In both years, breeding adults also consumed higher proportions of birds, especially shorebirds, than nonbreeding gulls did. Subadults may not yet have the skills to hunt live prey such as lemmings and shorebirds consistently, even when such prey is unusually abundant. These gulls may derive a substantial benefit from easily obtained anthropogenic foods. Garbage in diet can increase body condition of gulls (Auman et al., 2008), and proximity to anthropogenic food sources can improve survival of American crows (Corvus brachyrynchos; Marzluff and Neatherlin, 2006); it is likely that garbage could improve survival to adulthood for immature gulls. The subadult gulls using the Barrow landfills move widely throughout the ACP, western Arctic Canada, and coastal Russia during the summer (Declan Troy, Troy Ecological Research Associates, pers. comm.), staying only briefly (up to a week) in any given area, and they may eventually breed anywhere in the region. Anthropogenic subsidies in any one location could therefore affect breeding gull population sizes throughout the western Arctic.
Although incineration was apparently effective in reducing the amount of garbage in nonbreeding gull diet, garbage remained an important component of that diet even after the change in disposal method. Storage methods may be as important as disposal in regulating waste availability; open dumpsters offer ready access to garbage for avian scavengers. Effective waste control at all stages of disposal will be a necessary step in limiting the negative indirect effects of future development on wildlife.

\section{ACKNOWLEDGEMENTS}

This study was funded by the North Slope Borough Department of Wildlife Management (with a grant from NPR-A Impact Mitigation Program, Alaska Department of Commerce, Community, and Economic Development), the U.S. Bureau of Land Management (Arctic Field Office), and a University of Alaska Foundation Angus Gavin Migratory Bird Research Grant. We thank Ruby Baxter for assistance with sample collection and analysis and Robert Suydam and Debbie Nigro for logistical support. Debbie Nigro, Declan Troy, Christine Hunter, Alan Springer, and three anonymous reviewers provided comments that improved the manuscript. This study was conducted under approval \#07-46 of the Institutional Animal Care and Use Committee of the University of Alaska Fairbanks. Any use of trade, product, or firm names in this publication is for descriptive purposes only and does not imply endorsement by the U.S. Government.

\section{REFERENCES}

Alaska Shorebird Group. 2008. Alaska Shorebird Conservation Plan, Version II. Anchorage: Alaska Shorebird Group. 94 p. http://alaska.fws.gov/mbsp/mbm/shorebirds/plans.htm.

Ashmole, N.P. 1963. The regulation of numbers of tropical oceanic birds. Ibis 103:458-473.

Auman, H.J., Meathrel, C.E., and Richardson, A. 2008. Supersize me: Does anthropogenic food change the body condition of silver gulls? A comparison between urbanized and remote, non-urbanized areas. Waterbirds 31:122-126, doi:10.1675/15244695(2008)31[122:SMDAFC]2.0.CO;2.

Chapdelaine, G., and Rail, J.-F. 1997. Relationship between cod fishery activities and the population of herring gulls on the North Shore of the Gulf of St. Lawrence, Québec, Canada. ICES Journal of Marine Science 54:708-713.

Conover, M.R. 1983. Recent changes in ring-billed and California gull populations in the western United States. Wilson Bulletin 95:362-383.

Contesse, P., Hegglin, D., Gloor, S., Bontadina, F., and Deplazes, P. 2004. The diet of urban foxes (Vulpes vulpes) and the availability of anthropogenic food in the city of Zurich, Switzerland. Mammalian Biology 69:81 -95, doi:10.1078/16165047-00123.

Curtis, P.D., Smith, C.R., and Evans, W. 1995. Techniques for reducing bird use at Nanticoke Landfill near E. A. Link 
Airport, Broome County, New York. Proceedings of the Eastern Wildlife Damage Control Conference 6:67-78.

Dickson, D.L., and Gilchrist, H.G. 2001. Status of marine birds of the southeastern Beaufort Sea. Arctic 55(Suppl. 1):46-58.

Duffy, D.C., and Jackson, S. 1986. Diet studies of seabirds: A review of methods. Colonial Waterbirds 9:1-17.

Duhem, C., Roche, P., Vidal, E., and Tatoni, T. 2008. Effects of anthropogenic food resources on yellow-legged gull colony size on Mediterranean islands. Population Ecology 50:91 - 100, doi:10.1007/s10144-007-0059-z.

Fordham, R.A., and Cormack, R.M. 1970. Mortality and population change of Dominican gulls in Wellington, New Zealand: With a statistical appendix. Journal of Animal Ecology 39:13-27.

Garrott, R.A., White, P.J., and White, C.A.V. 1993. Overabundance: An issue for conservation biologists? Conservation Biology 7:946-949, doi:10.1046/j.1523-1739.1993.740946.x.

Gaston, A.J., Descamps, S., and Gilchrist, H.G. 2009. Reproduction and survival of glaucous gulls breeding in an Arctic seabird colony. Journal of Field Ornithology 80(2):135-145, doi: 10.1111/j.1557-9263.2009.00215.x.

Gilchrist, H.G. 2001. Glaucous gull (Larus hyperboreus). In: Poole, A., and Gill, F., eds. The birds of North America online. Ithaca, New York: Cornell Laboratory of Ornithology.

Gompper, M.E., and Vanak, A.T. 2008. Subsidized predators, landscapes of fear and disarticulated carnivore communities. Animal Conservation 11:13-14, doi:10.1111/j.1469-1795.2008. 00160.x.

Gonzáles-Solís, J., Oro, D., Pedrocchi, V., Jover, L., and Ruiz, X. 1997. Bias associated with diet samples in Audouin's gulls. The Condor 99:773-779.

Goudie, R.I., Brault, S., Conant, B., Kondratyev, A.V., Petersen, M.R., and Vermeer, K. 1994. The status of sea ducks in the North Pacific Rim: Toward their conservation and management. Transactions of the North American Wildlife and Natural Resources Conference 59:27-49.

Harris, M.P. 1970. Rates and causes of increases of some British gull populations. Bird Study 17:325-335.

Holt, R.D. 1984. Spatial heterogeneity, indirect interactions, and the coexistence of prey species. American Naturalist 124: 377-406.

Kadlec, J.A., and Drury, W.H. 1968. Structure of the New England herring gull population. Ecology 49:644-676, doi: $10.2307 / 1935530$.

Kurosawa, R., Kanai, Y., Matsuda, M., and Okuyama, M. 2003. Conflict between humans and crows in greater Tokyo: Garbage management as a possible solution. Global Environmental Research 7:139-147.

Larned, W.W., Stehn, R.S., and Platte, R.M. 2010. Waterfowl breeding population survey, Arctic Coastal Plain, Alaska 2009. Soldotna, Alaska: U.S. Fish and Wildlife Service, Division of Migratory Bird Management.

Liebezeit, J.R., Kendall, S.J., Brown, S., Johnson, C.B., Martin, P., McDonald, T.L., Payer, D.C., et al. 2009. Influence of human development and predators on nest survival of tundra birds, Arctic Coastal Plain, Alaska. Ecological Applications 19: 1628-1644, doi:10.1890/08-1661.1.
MacLean, A.A.E. 1986. Age-specific foraging ability and the evolution of deferred breeding in three species of gulls. The Wilson Bulletin 98:267-279.

Marzluff, J.M., and Neatherlin, E. 2006. Corvid response to human settlements and campgrounds: Causes, consequences, and challenges for conservation. Biological Conservation 130(2):301 - 314, doi:10.1016/j.biocon.2005.12.026.

National Research Council. 2003. Cumulative environmental effects of oil and gas activities on Alaska's North Slope. Washington, D.C.: The National Academies Press.

Noel, L.E., Johnson, S.R., and Gazey, W.J. 2006. Oilfield development and glaucous gull (Larus hyperboreus) distribution and abundance in central Alaskan Beaufort Sea lagoons, 1970-2001. Arctic 59:65-78.

Poole, A., ed. 2007. The birds of North America online. Ithaca, New York: Cornell Laboratory of Ornithology.

R Development Core Team. 2009. R: A language and environment for statistical computing. Vienna, Austria: R Foundation for Statistical Computing. Available online at http://www.Rproject.org.

Searcy, W.A. 1978. Foraging success in three age classes of glaucous-winged gulls. Auk 95:586-588.

Skórka, P., and Wójcik, J.D. 2008. Habitat utilisation, feeding tactics and age related feeding efficiency in the Caspian gull Larus cachinnans. Journal of Ornithology 149:31-39, doi: 10.1007/s10336-007-0208-3.

Spear, L.B. 1988. Dispersal patterns of western gulls from southeast Farallon Island. The Auk 105:128-141.

Springer, H. 1987. Population trends in glaucous gulls (Larus hyperboreus) and ravens (Corvus corax) at Nome, Alaska (abstract only). In: Alaska Bird Conference and Workshop, Juneau, Alaska.

Steenhof, K., Kochert, M.N., and Roppe, J.A. 1993. Nesting by raptors and common ravens on electrical transmission line towers. Journal of Wildlife Management 57:271 - 281.

Suydam, R.S., Dickson, D.L., Fadely, J.B., and Quakenbush, L.T. 2000. Population declines of king and common eiders of the Beaufort Sea. The Condor 102:219-222.

USFWS (U.S. Fish and Wildlife Service). 2003. Human influences on predators of nesting birds on the North Slope of Alaska: A public workshop. Fairbanks Fish and Wildlife Field Office, 17-18 April 2003, Anchorage, Alaska.

- 2005. Waterfowl population status, 2005. Washington, D.C.: U.S. Department of the Interior.

Votier, S., Bearhop, S., Ratcliffe, N., and Furness, R.W. 2001. Pellets as indicators of diet in great skuas Catharacta skua. Bird Study 48:373-376.

Weiser, E.L. 2010. Use of anthropogenic foods by glaucous gulls (Larus hyperboreus) in northern Alaska. MSc thesis, University of Alaska Fairbanks, Alaska.

Weiser, E.L., and Powell, A.N. 2010. Does garbage in the diet improve reproductive output of glaucous gulls? The Condor 112:530-538, doi:10.1525/cond.2010.100020.

Yorio, P., Bertellotti, M., Gandini, P., and Frere, E. 1998. Kelp gulls Larus dominicanus breeding on the Argentine coast: Population status and relationship with coastal management and conservation. Marine Ornithology 26:11-18. 